\title{
PROMOOTIOKULTTUURIN KUNINGAS KEKKONEN
}

1 Kiitämme tarinasta tekstissä mainittua opettajaa, KSYK:n Yhteiskunta- ja talouslinjan johtajaa.
Kekkonen on hottis! Vuonna 2016 Kulosaaren yhteiskoulun yhdeksäsluokkalaiset näkivät yhteiskuntaopin tunnilla videon Kekkosesta, jossa Kekkonen teki kaikkea, mitä Kekkonen teki: puhui, kalasti, hiihti, tapasi maailman johtajia. Kun video oli ohi, oppilaat puhkesivat spontaaneihin aplodeihin. 1970-luvulla syntynyt opettaja oli puulla päähän lyöty. ${ }^{1}$ Samat nuoret kuuntelevat Cheekiä, joka laulaa Chekkosesta. Kun räppäri haluaa kehua itseään estottomasti ja rinnastaa itsensä johonkuhun suurmieheen, tarkoitukseen paras on Kekkonen.

Presidentti Urho Kaleva Kekkosen kuolemasta tulee tänä syksynä 30 vuotta. Kekkonen hallitsi Suomea neljännesvuosisadan ajan. Monille hän oli synonyymi sanalle presidentti. Tässä Kekkoselle omistetussa erikoisnumerossa suuntaamme katseen Kekkosen johtajuuteen mediakulttuurin ja mediahistorian näkökulmista. Historioitsijat ja politiikantutkijat ovat kirjoittaneet Kekkosesta hyllymetreittäin, mutta median ja viestinnän tutkimuksen puolella menneisyyttä ruotiva Kekkoseen liittyvä tutkimus on ollut jokseenkin vähäistä (ks. kuitenkin Salokangas 1996; Kantola 2014; Sumiala 2014). Median jatkuva murros haastaa tutkijoita katsomaan nykyhetkeen ja pohtimaan tulevaisuutta. Tässä nyt-hetkeä korostavassa tutkimusilmapiirissä historiallinen tutkimusote uhkaa jäädä marginaaliseksi. On silti perusteltua ajatella, että juuri muutosten merkityksen ymmärtämiseksi tarvitaan historiallista otetta.

Tämän päivän media- ja viestinnäntutkimuksessa keskustellaan vilkkaasti brändi- ja promootiokulttuurin leviämisestä yhteiskunnan eri alueille, yhtenä esimerkkinä politiikka. Tässä tuotteistetun ja formatoidun viestinnän mediakyllästeisessä maailmassa "tapaus Kekkonen" avaa tärkeän ajallisen horisontin ja näkökulman siihen, miten poliittisesta vallasta on eri aikoina viestitty. Mikä on muuttunut, mikä pysynyt samana.

Kekkosesta voi hyvällä syyllä sanoa, että hänelle presidenttiys oli rooli, josta olisi voitu myöntää Hollywoodin Oscar-palkinto. Kekkonen oli aikaansa edellä poliittisena viestijänä ja julkisuuden taitavana hyväksikäyttäjänä. Hän osasi käyttää ajan joukkoviestimiä, kuten sanomalehtiä, radiota ja televisiota, hyväkseen. Hän osasi myös hyödyntää henkilökohtaista viestintää, kuten kirjeenvaihtoa, niin kansalaisten kuin poliittisen eliitinkin puhuttelemiseen. Timo J. Tuikka on väitöskirjassaan (2007) tarkastellut Kekkosen historia- ja politiikkakäsityksiä ja osoittaa selvästi Kekkosen strategisuuden julkisen kuvan rakentamisessa. Kekkosen pitkäaikaiset taustavoimat, kuten kansatieteen professori Kustaa Vilkuna, toimivat sen aikaisina poliittisina konsultteina. 
Mediahistoriallisesta näkökulmasta on tärkeää huomioida mediaympäristön muutos ja sen merkitys Kekkosen poliittiselle viestinnälle. Kekkosen ura ja hallintokausi oli pitkä, ja sen aikana suomalaiset tiedotusvälineet kokivat monta mullistavaa kehitysvaihetta. Samaan aikaan, kun Kekkonen käytti eri välineitä oman johtajuutensa vahvistamiseen ja oman julkisen kuvansa systemaattiseen rakentamiseen, myös joukkoviestimet oikeuttivat oman olemassaolonsa rakentamalla kuviteltua yhteisöä kansakunnasta. Kekkosen uran alkuaikojen - vuosien 1937-1967 - radiopuheita tarkastelevassa artikkelissaan Jukka-Pekka Puro kiinnittää erityistä huomiota Yleisradion rooliin ja merkitykseen tässä kansakunnan koossapitämisprojektissa. Yleisradiolla ja Kekkosella oli ikään kuin molemmilla monopoliasema, ja ne hyödyttivät toinen toisiaan. Kekkosen tiiviit suhteet Yleisradion johtoon, jonka edustuksesta Puro mainitsee tuolta ajalta Kustaa Vilkunan ja Jussi Koskiluoman, olivat tunnettuja. Myöhemmin, kuohuvalla 1960-luvulla, Yleisradion pääjohtaja Eino S. Repo kuului Kekkosen lähipiiriin, ja tämä heijastui eri tavoin "Reporadion" aikaan.

Television yleistyttyä Kekkonen "livahti koteihimme", kuten asian on nasevasti ilmaissut Kekkosen luottokuvaaja Kalle Kultala. Kekkonen käytti taitavasti poliittisen imagonsa rakentamisessa niin liikkuvaa kuvaa kuin valokuviakin. Kiinnostavana esimerkkinä Kekkosen filmaattisuudesta voidaan pitää varhaisia Finlandia-filmikatsauksia, joita tarkastellaan Minna Lammin ja Päivi Timosen artikkelissa. Nämä katsaukset tarjosivat Kekkoselle seremoniallisen ja sitä kautta "epäpoliittisen" tavan viestiä kansalle ensimmäisenä presidenttikautenaan.

Kekkosen kaudella korostui varovainen journalismi ja suoranainen itsesensuuri suhteessa Kekkoseen ja Neuvostoliittoon, mutta kuva ei ollut täysin särmätön. Helsingin Sanomat käytti yksityisenä yrityksenä ja valtakunnallisesti merkittävimpänä sanomalehtenä asemaansa myös hallitsijan kritisoimiseen. Katsauksessaan Jukka Rastas tuo esille, miten "toinen kuningas" eli pilapiirtäjä Kari Suomalainen tuotti Kekkosesta kuvaa itsevaltaisena hallitsijana. Samalla Rastas kuitenkin toteaa, että pilapiirtäjä olemassaolollaan loppujen lopuksi myös edesauttoi Kekkosen pyrkimystä rakentaa Suomesta kuvaa puolueettomana länsimaisena demokratiana.

Kun Kekkosen tapaa viestiä valtaa tarkastellaan mediakulttuurin näkökulmasta, katse kiinnittyy erityisesti kolmeen asiaan: kuvaan, ääneen ja tunteisiin. Lehti- ja televisiokuvat kuvauksellisesta Kekkosesta levisivät joukkoviestimissä, ja niistä tuli osa kansakunnan kuvallista tajuntaa ja muistia. Kekkonen tuotti suvereenia (mieli)kuvaa itsestään johtajana valokuvilla ja filminpätkillä, joissa hän näyttäytyi maailmanmatkoillaan, valtiovierailujen isäntänä, naisten ympäröimänä ja tärkeiden valtakunnallisten puheiden pitäjänä. Tämän valtiomies-Kekkosen lisäksi olennaista vallan viestimisessä oli arkinen "Kekkonen kansanmiehenä" -kuvasto, jossa presidentti esitti itsensä kansan parissa kalastamassa, hiihtämässä ja erätulilla, maakuntien emäntiä ja isäntiä tapaamassa tai saunan lauteilla löylyä heittämässä.

Kekkosen kuoleman uutisointia käsittelevässä artikkelissa toteamme, että tämä rituaalinen kuvasto ja siihen liittyvä puheenparsi toistettiin valtakunnallisessa mediassa uskollisesti. Seremonialliset jäähyväiset saivat näkyvästi tilaa niin televisiossa kuin valtakunnan sanomalehdissäkin, ja niillä pönkitettiin vielä kerran Kekkosen valtaa suomalaisessa yhteiskunnassa.

Kekkosen ääni oli hyvin tunnistettava ja selkeä, ja pitkään radion kuuntelijat assosioivat sen Yleisradioon. Molemmat toivat toisilleen uskottavuutta. Nykyään korostetaan niin kutsuttuja one linereita poliittisessa viestinnässä, mutta jo Kekkonen muotoili asiansa lyhyesti ja ymmärrettävästi. Hän vetosi 
puheissaan hillitysti tunteisiin - paatoksellisuuden jo uransa alkuvaiheessa karistaneena. Sen sijaan huumori kuului vahvasti Kekkosen ilmaisurepertuaariin. Näkökulmassaan Timo Soikkanen tuo esiin, miten Kekkoselle tyypillinen ironinen ja ivallinen viestintätapa toimi vallankäyttönä.

Kekkonen elää edelleen vahvana suomalaisessa mediakulttuurissa. Tomi Lindblomin teksti avaa erityisen mediakuluttuurisen näkökulman Kekkosen ja kansalaisten väliseen yhteydenpitoon esittelemällä nimikirjoitusten keräilykulttuuria ja Kekkoselle lähetettyjä lukuisia nimikirjoituspyyntöjä. Paitsi poliitikko, Kekkonen oli myös aikansa superkuuluisuus. Tuomas Lassinharjun katsaus "Mies mekkonen" esittelee taiteilijoiden Kekkos-kuvaa populaarimusiikin sanoituksissa. Olli Seurin aiheena on puolestaan historiakuva, joka Helsingin Sanomien Kekkos-viittauksista välittyy. Seuri muistuttaa, ettei menneisyydestä ole löydettävissä yhtä yhtenäistä kertomusta tai tulkintaa.

Tämän erikoisnumeron toimittajina ajattelemme, että mediakulttuurin ja -historian näkökulmat ovat tarpeen juuri siksi, että ne monisärmäistävät ymmärrystä Kekkosesta poliittisena viestijänä ja vallankäyttäjänä. Parhaimmillaan menneisyyden moniulotteinen tarkastelu auttaa ymmärtämään myös tätä päivää - ajassa, jossa medialla on yhä suurempi merkitys poliittisten mielikuvien ja vallan promoottorina.

Helsingissä, heinäkuussa 2016

Lotta Lounasmeri ja Johanna Sumiala

\section{Lähteet}

Kantola, Anu (2014) Matala Valta. Tampere: Vastapaino.

Salokangas, Raimo (1996) Aikansa oloinen. Meisradion historia 1949-1996. Helsinki: Yleisradio Oy. Sumiala, Johanna (2014) "Ritualising Public Death in the Nordic Media". Teoksessa Dorthe Resflund Christensen \& Kjetil Sandvik (toim.) Mediating and Remediating Death. Farnham: Ashgate Publishing.

Tuikka, Timo J. (2007) "Kekkosen konstit": Urho Kekkosen historia- ja politiikkakäsitykset teoriasta käytäntöön 1933-1981. Jyväskylä: Jyväskylä University Printing House.

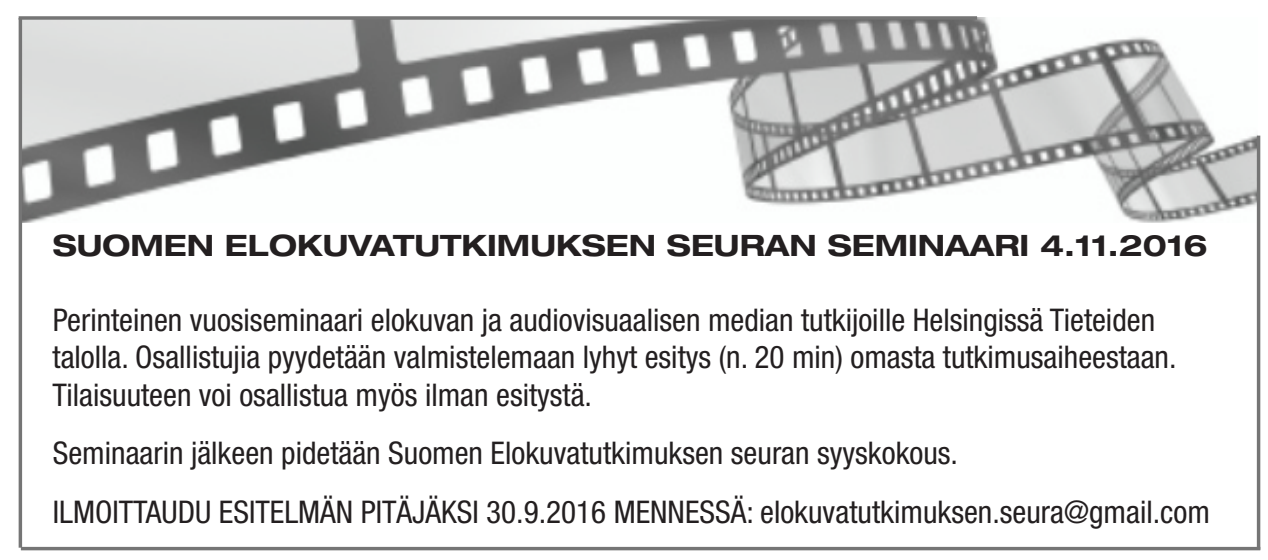

